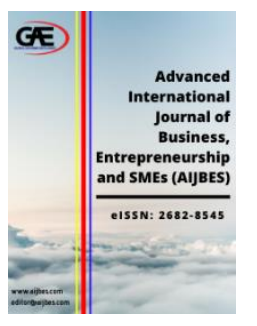

\author{
ADVANCED INTERNATIONAL JOURNAL OF \\ BUSINESS, ENTREPRENEURSHIP AND SMES \\ (AIJBES) \\ www.aijbes.com
}

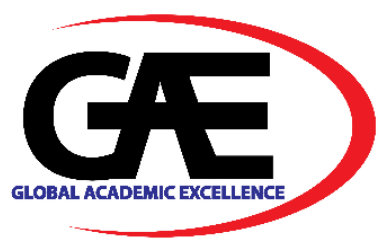

\title{
IMPLEMENTATION PLAN ON LEARNING ORGANIZATION PRACTICE TO INCREASE BUSINESS PERFORMANCE OF SAVLEE COMPANY
}

\author{
Fatimah Az-Zahra ${ }^{1 *}$, Emilia Fitriana Dewi ${ }^{2}$ \\ 1 School of Business and Management, Institut Teknologi Bandung, Indonesia \\ Email: fatimah_azzahra@sbm-itb.ac.id \\ 2 School of Business and Management, Institut Teknologi Bandung, Indonesia \\ Email: emilia.f@sbm-itb.ac.id \\ * Corresponding Author
}

\section{Article Info:}

\section{Article history:}

Received date: 25.08 .2021

Revised date: 15.09 .2021

Accepted date: 25.09 .2021

Published date: 30.09 .2021

\section{To cite this document:}

Az-Zahra, F., Dewi, E. F. (2021). Implementation Plan On Learning Organization Practice To Increase Business Performance Of Savlee Company. Advanced International Journal of Business, Entrepreneurship and SMEs, 3 (9), 362-376.

DOI: $10.35631 / \mathrm{AIJBES} .39024$.

This work is licensed under CC BY 4.0 ()(1)

\begin{abstract}
:
Cessa previously ran a technology-based business by creating therapeutic tools to reduce sleep problems. Since the pandemic era, the research and development process has been hampered due to limited access to laboratories. Therefore, the company pivoted to the Savlee company by creating a dailywear sleeping product. There are several problems and challenges that arise in the business model. Savlee began to try a new approach in the fields of pharmacy, psychology, and neuroscience. Savlee needed to have initial learning and should seek a new form of data and information that became the main reference. The data analysis process was carried out using qualitative data methods with in-depth interviews and focus group discussions. Based on the House of Learning Organization by Jann Model as the model of learning organization practices that consist of learning foundations, learning facilities, learning skills, learning enablers, and learning disciplines, and plan for the implementing practice of learning organizations using Peter Senge's methods in "The Dance of Change-Generating Profound Change." The outcome of this research is a plan for implementation of the learning organization, which consists of three stages, starting with building individual personal mastery, team learning ability, and organizational learning ability. Therefore, Savlee must implement a suitable learning organization with appropriate design and organizational learning that has a clear measurement for the evaluation of business performance.
\end{abstract}

Keywords:

E Business Change, Leaning Organization Practice, Business Performance, House of Learning of Organization Jann Model, The Dance of ChangeGenerating Profound Changes 


\section{Introduction}

Savlee is a company that focuses on solving sleeping issues through daily-wear sleeping products with organic and natural ingredients. The business's core purpose is to improve sleep quality through daily-wear sleeping products by giving natural therapeutic products to improve sleep quality without causing addictive effects. Savlee has launched several product lines, such as pillow mist, aromatherapy roll-on, foot soak, sleep eye mask, aromatherapy candle, and tea.

By doing this research, the researchers want to arrange the learning organization practice at Savlee Company after pivoting the business model. The result of this research will develop a new set of plans for implementing the learning organization practices at Savlee Company after pivoting the business model. The findings of the study will be used to improve the learning culture and the overall performance of the Savlee Company. This will provide a clear picture for the company to find out what the most suitable learning organization practice is and the parameters for evaluating the plan implementation of learning organization practices at Savlee Company.

\section{Literature Review}

\section{Xerox's Problem Identification Process}

In building a learning organization, the company focuses mainly on problem identification techniques using practical methods. This problem identification technique is relatively easy to communicate and requires a change in mindset. Therefore, employees must become more critical in their thinking and pay more attention to details so that the learning process can be created. Xerox senior managers launched the company's Leadership Through Quality initiative. In practice, all employees are trained in small group activities and problem identification techniques. By analysing Xerox's Problem Identification Process, Savlee will know about the root causes of the problem in the company and have clear evidence as the basis for making decisions for implementing learning organization practice. This will support the right reasoning for a decision and the learning process will run smoothly.

\section{House of Learning Organization (Jann Model)}

In a knowledge-based company or organization, all activities must have a knowledge-base approach (Jann Hidayat, 2006). In the application of the learning process, the effectiveness of the organizational learning process is determined by the quality of the three elements of the learning organization (humans, technology, and their habitat). After knowing the root cause problem in the company, Savlee must analyse the readiness of fundamental factors on implementing learning organization practice to show the importance of the learning organization as a whole system compared to a partial approach. There is a learning organization building, which is composed of learning components. In Jann's House of Learning Organization Model (2006), there are several fundamentals for applying knowledge to an organization or company as the foundation of learning organization practice that consist of learning foundations, learning facilities, learning skills, learning enablers, and learning disciplines.

\section{Implementing Learning Organization Practice}

According to Peter Senge (1990:3) learning organizations are organizations where people continually expand their capacity to create the results they truly desire, where new and expansive patterns of thinking are nurtured, where collective aspiration is set free, and where people are continually learning to see the whole together. 


\section{The Operationalization of Building a Learning Organization}

After knowing the readiness of fundamental factors learning organization in Savlee, the author conducted a readiness test to change towards a learning organization by referring to practical steps to start efforts to build a learning organization developed by Peter Senge, namely The Dance of Change-Generating Profound Changes. The steps of a profound change process to realize a model learning organization consist of the following three stages of change:

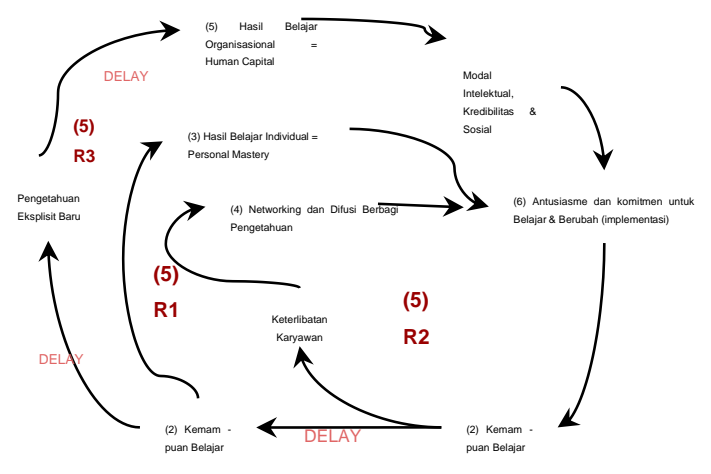

Figure 1: The Process of Change Towards a Learning Organization

Source: Tjaakraatmadja, J. H. (2006). Knowledge Management dalam Konteks Organisasi Pembelajar. SBM-ITB (Sekolah Bisnis dan Management - Institut Teknologi Bandung. ISBN 979-5458-0-4

1. $\mathrm{R} 1=$ Building Individual Learning Skills to Produce Personal Mastery The target of the first stage (start-up stage) is to build employees into Personal Mastery, who have the ability or knowledge and skills to develop new knowledge so as to create innovation or organizational improvement.

a. Build an Inner shift

The success of building inner shifts at the start-up stage is highly dependent on the ability of the company to prepare leaders who have multiple skills (multiskills), as visionary, synergistic, and transformational leaders at the same time.

b. Build Outer shift

The effectiveness of the leadership of the learning organization will be more effective if it is assisted by the existence of an outer shift, which in this case is in the form of the availability of systems and organizations that lead to changes in employee behavior.

2. $\mathrm{R} 2=$ Building Team Learning Ability, to Increase the Effectiveness of the Knowledge Sharing Process Between Members

Improve the effectiveness of the team's learning abilities supported by the process of sharing knowledge among members with enthusiasm, enthusiasm, and a strong will to remain committed to the network.

3. R3: Building Organizational Learning Ability to Generate Human Capital.

To produce organizational human capital, which can be realized with intellectual capital, credibility capital, or organizational social capital. and, in the end, will have new explicit knowledge. The final step is to prepare the findings of new explicit knowledge to be implemented and then proceed to the next profound change process so that a continuous learning and change process is obtained. 
Volume 3 Issue 9 (September 2021) PP. 362-376 DOI 10.35631/AIJBES.39024

To complete the instrument for the change team members, at the initial stage the pilot group can also carry out diagnostics to measure the level of readiness of the organization in making organizational changes, from traditional organizations to learning organizations, by doing Test readiness for change, using the questionnaire "Test readiness for change towards a learning organization" by Calhoun WW and Lu Staton Leon (1995).

\section{The Readiness to Change Towards a Learning Organization (Calhoun WW and Staton Leon - 1995)}

The author also carries out diagnostics to measure the level of readiness of the organization to make organizational changes, from traditional organizations to learning organizations. This assessment was conducted to find out whether the Savlee company is ready to turn into a learning organization and whether through this test it can be input for Savlee to pay attention to the indicators that must be completed to turn into a learning organization. The A Readiness Test to Change Towards a Learning Organization was conducted by doing Test readiness for change, using the questionnaire "Test readiness for change towards a learning organization" by Calhoun WW and Lu Staton Leon (1995).

\section{Conceptual Framework}

Based on the results of problem identification in Savlee's company, it is necessary to arrange the learning organization practice at Savlee Company after pivoting the business model to increase the business productivity of Savlee. According to the previous study, the researchers decided to use several variables which will be researched. The previous study shows some variables that will be researched to determine the indicators that build a learning organization, such as: leadership, learning foundations, learning skills, learning facilities, and learning discipline. These indicators will be the basic capital for organizations to build learning organizations that consist of elements of learning habitats in organizations that function as a medium for the learning process to occur. In addition, there is also a diagnosis to measure the level of an organization's readiness to make organizational changes, from traditional organizations to learning organizations by conducting a readiness test to change to a learning organization. 


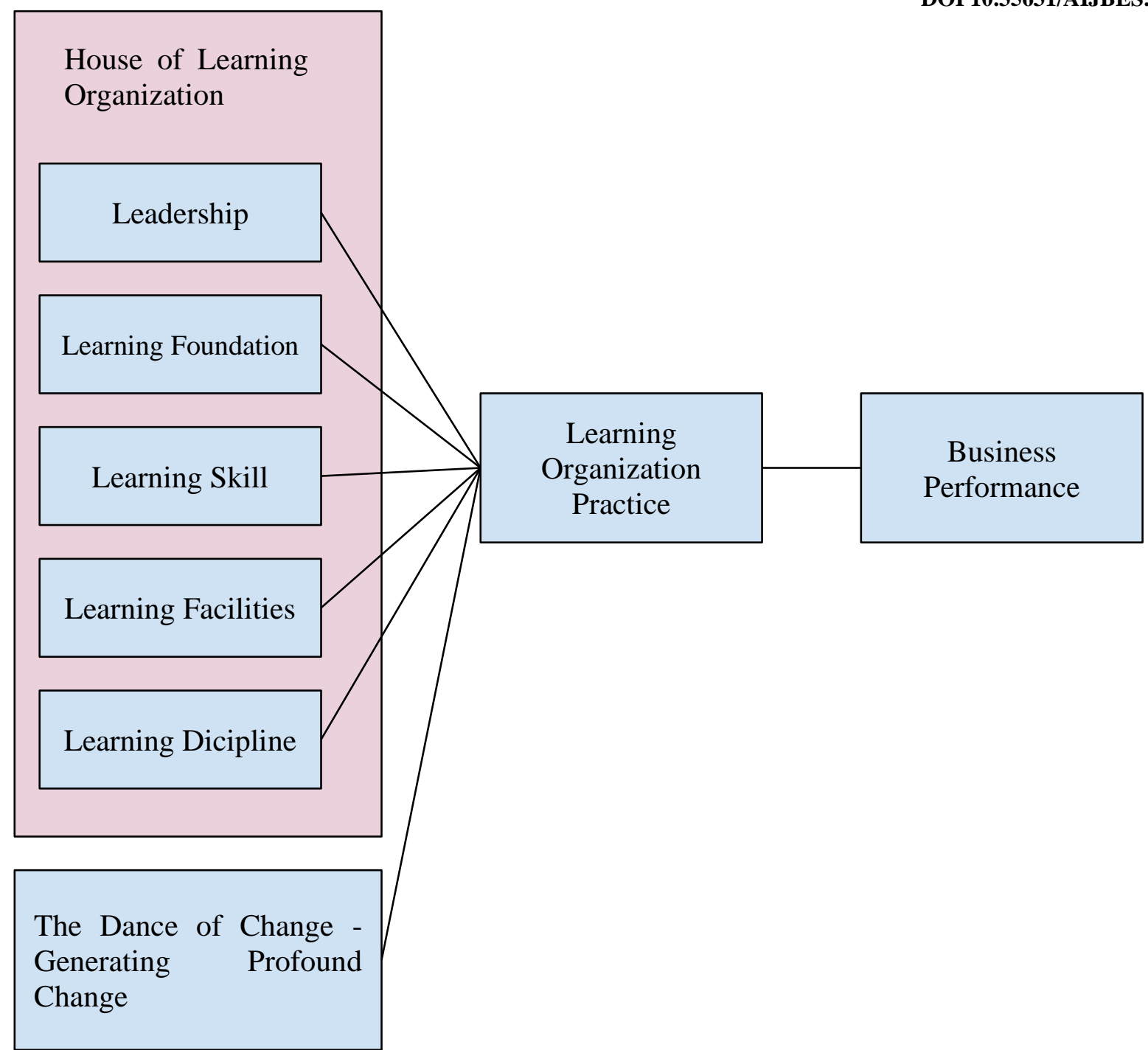

Figure 2: Conceptual Framework

\section{Methodology}

The research design of this study starts from problem identification to drawing conclusions. In identifying the problem, the authors try to identify the problem by analyzing the root cause of the problem by Xerox's Problem Identification process, which will be used in chapter I as an introduction. With the changes in this business, there are several problems and challenges that arise that hinder Savlee's business productivity. The change in the business model represents a significant change in Savlee's business progress. The next step is a business review by using secondary data from preliminary research results by Hedwika Avila Diva to describe the business conditions of Savlee. Based on the results of problem identification in Savlee's company, it is necessary to arrange the learning organization practice at Savlee Company after pivoting the business model to increase the business productivity of Savlee. After that, the authors collected a literature review for chapter 3 as a theoretical foundation for the research framework in this study. According to the previous study, the researchers decided to use House of Learning Organization Jann Model to analyze fundamental factors to implement learning organization practice to be a lerning building in Savlee. There are several fundamental factors, such as: leadership, learning foundations, learning skills, learning facilities, and learning discipline. In addition, there is also a diagnosis to measure the level of an organization's Copyright $\odot$ GLOBAL ACADEMIC EXCELLENCE (M) SDN BHD - All rights reserved 
Volume 3 Issue 9 (September 2021) PP. 362-376

DOI 10.35631/AIJBES.39024

readiness to make organizational changes, from traditional organizations to learning organizations by conducting a readiness test to change to a learning organization organization that referring to practical steps to start efforts to build a learning organization developed by Peter Senge, namely The Dance of Change-Generating Profound Changes. The steps of a profound change process to realize a model learning organization. Next is to prepare the data collection method that will be explained in the data collection section based on. After the data is collected, the author can process and analyze the data, then explain the results. The final step is to make conclusions from the analysis of the research results.

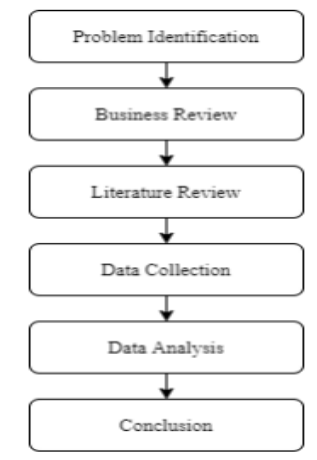

Figure 3: Methodology

\section{Result \& Discussion}

\section{Xerox's Problem Identification Process}

During this pandemic, the Savlee company was forced to make a business pivot. From previously running a technology-based business, Savlee is trying to pivot to a new business model by creating a daily-wear sleeping product to solve consumer problems. With the changes in this business, there are several problems and challenges that arise that hinder Savlee's business productivity. The change in the business model represents a significant change in Savlee's business progress. Savlee's business changes have brought significant changes to the target market. Due to the pivot of this business model, Savlee began to study a new approach in the fields of pharmacy, psychology, and neuroscience. Because Savlee did not have initial learning and there was no source of information that became the main reference, the exploration of information and knowledge carried out by each member became very broad and varied.

Based on the results of problem identification in Savlee's company, it is necessary to implement an appropriate learning organization for Savlee to improve business performance, create new knowledge, create change (work improvement, improvisation), and process or product innovation (capable of creating new value for products). This is supported by a learning organization building, which is composed of "organizational building" components such as Leadership, Learning Foundations, Learning Skills, Learning Facilities, and Learning Disciplines.

\section{House of Learning Organization Jann Model}

The author identifies Jann's House of Learning Organization Model to know fundamentals for applying knowledge to Savlee company as the foundation of learning organization practice that consists of: 
1. Learning foundations

The learning habitat as a "foundation" within the Savlee company itself, among its members, is sufficient to fulfill 2 components of a good learning habitat, such as the climate of trust to support the exchange of knowledge/information between members and the existence of a learning culture in Savlee.

2. Learning facilities

a. Systematic Information

Based on the interview results, it is known that the quality of the availability of systemic information in Savlee is quite good, which is characterized by the number of reliable and accessible sources of information (network density), the ability of the system to reach the required sources of information/knowledge (network linkage), the ability of the system to can relate directly to information sources (network hierarchy), the availability of facilities that can receive important information well, know who needs it, so that it can distribute it effectively, the ability to communicate with the right sources (quality), the ability to communicate with sources who are willing to share knowledge (reliability), and the ability to get a response from a knowledge source quickly (speed).

b. Organizational Structure

Based on the interview results, it is known that the organizational structure component in Savlee still needs to be improved. Savlee has an organizational structure that is able to flow information with minimal obstacles so that it can flow information quickly and smoothly. The division of labor at Savlee is also very flexible. However, Savlee had to design a coordination system and control system to make it more effective. This coordination system and control system must be able to provide openness and control roles of each member on the performance of each other's divisions.

c. Reward system

Based on interviews, Savlee does not yet have a formal award/recognition system for achievements. However, Savlee members are used to giving awards/recognition for these achievements verbally (informally), and this is enough to provide motivation and enthusiasm for work within the company. At Savlee, the employee development (training) system has been implemented fairly and sustainably.

3. Learning skills

In Savlee, its members have been able to meet the criteria for skills that are able to support this, including systematic problem solving skills, experimenting skills using new approaches, the ability to learn from past experience and history, the ability to learn from successful practitioners (other organizations) (benchmarking), and the ability to transfer knowledge quickly and efficiently. Where knowledge workers are effective as pillars of learning organizations that support workers to become active and sustainable learners.

4. Learning enablers

In accordance with the business conditions at Savlee, Savlee requires learning enablers or leaders who are able to meet the needs of current employees, including coaching others, communicating effectively, developing competencies in others, building 
Volume 3 Issue 9 (September 2021) PP. 362-376

DOI 10.35631/AIJBES.39024

commitment for others, and ensuring contribution. Based on this, Savlee needs a coach type of leader to support the process of changing the Savlee company into a learning company.

5. Learning disciplines

This discipline illustrates how Savlee members carry out thought processes, dialogues, and share knowledge effectively so that Savlee is able to develop member intelligence and company capacity.At Savlee, all members have met the learning team discipline indicators, such as :

a. They have the ability and habit of understanding each other or the ability to build mutual agreement.

b. Willing and able to carry out intelligent cooperation so that there is a process of enriching insight and views

c. Savlee members have a high ability to carry out the dialogue process (share values, share vision, or share knowledge) to build shared intelligence.

With the fulfillment of the five disciplines of Peter Senge's (1994) learning organization, it can act as a developmental path for acquiring certain skills or competencies to organization capital. The fulfillment of the five disciplines of Peter Senge's learning organization (1994), indicates that there is a harmonious relationship between humans and habitat as human capital in building learning organization practice.

\section{Test Readiness For Change Towards A Learning Organization By Calhoun WW And Lu Staton Leon (1995)}

To complete the instrument for the change team members, at the initial stage, the pilot group can also carry out diagnostics to measure the level of readiness of the organization to make organizational changes, from traditional organizations to learning organizations, by identifying:

\section{The quality of the learning habitat or test the maturity of members}

Based on the learning quality test and member maturity test using the House of Learning Organization Jann model (2006), it is known that Savlee has met the indicators of good learning habitat quality, which is characterized by the existence of a correlation between the five disciplines of learning organizations in shaping the path of knowledge transformation, such as:

1. The strong correlation of the five learning disciplines is able to make the knowledge transformation path of the learning organization better (Correlation value).

2. The quality of the learning organization's knowledge transformation path has a positive effect on each other (Correlation sign).

3. The significance of the correlation value indicates the quality of the knowledge transformation path of the learning organization that influences each other effectively.

In addition, Savlee members are mature. Marked by the fulfillment of all components of the learning discipline as a path of knowledge transformation, namely personal mastery discipline, sharing discipline, mental model discipline, systematic thinking discipline, and learning team discipline. The existence of maturity in Savlee members is also in line with Jann Hidayat's research in 2001, which concluded that the process of sharing knowledge requires a learning 
Volume 3 Issue 9 (September 2021) PP. 362-376 DOI 10.35631/AIJBES.39024

habitat that is based on mutual trust between members in dialogue, belief in the growth of the process of educating each other and producing mutual benefits.

2. The readiness to change towards a learning organization (Calhoun WW and Staton Leon - 1995)

From the results of the readiness test to change towards a learning organization, there are several implementation steps that must be taken to meet the indicators of a learning organization, including:

1. Conduct a dialogue process (share values, share vision, or share knowledge) to build shared intelligence and attract commitment from each member to form Savlee as a learning company.

2. Develop a comprehensive smart work plan as an organizational learning implementation process starting from the preparation stage, identification stage, habitat building stage, organizational learning implementation stage, and evaluation stage. At this stage, they will produce a classwork plan as well as performance measurement tools (process, progress, and results) that are effective in building organizational learning.

3. Creating a learning habitat that is able to motivate and support members to create innovations for solving problems and challenges that arise from Savlee's business changes.

\section{The Implementation Of The Learning Organization Plan}

Set of plans for implementing the learning organization practices at Savlee Company after pivoting the business model.

At this stage, it aims to build an organizational learning habitat to increase the effectiveness of team learning abilities. Savlee needs to implement the following planning process, such as:

\section{Vision and Objectives or Targets of Organizational Learning.}

Savlee has the vision to be a pioneer in the sleeping aid industry in Indonesia and to increase the market share of Savlee. With the mission of providing a high-quality personal care sleeping product to increase sleep quality, spread awareness and give education about the importance of maintaining health and sleep quality, Savlee provides alternative solutions to improve sleep quality without addictive effects.

In building a learning organization, Savlee has several objectives, including:

a. Savlee must conduct a dialogue process (share values, share vision, or share knowledge) to build shared intelligence and attract commitment from each member to form Savlee as a learning company.

b. Develop a comprehensive smart work plan as a coordination and control system for the implementation learning organization. Starting from the preparation stage, identification stage, habitat building stage, organizational learning implementation stage, and evaluation stage. It will produce a roadmap and OKR as performance measurement tools (process, progress, and results) that are effective in building organizational learning.

c. Creating a learning habitat that is able to motivate and support members to create innovations for solving problems and challenges that arise from Savlee's business changes. 


\section{Objective Key Result}

At this stage, Savlee must explain the policies and governance of the learning organization, in particular, by explaining the duties and authorities of each member, clarifying job descriptions and knowledge flow models to create fairness and transparency of workload between members. The linkage of these components will support the knowledge sharing process to be more effective and able to disseminate information quickly, on target, and accurately.

The following is the Objective Key Result of Savlee:

Table 1 Objective Key Result

\begin{tabular}{|c|c|c|}
\hline Objective & Description & PIC \\
\hline \multirow{3}{*}{$\begin{array}{l}\text { Raising } \\
\text { Awareness in } \\
\text { Social Media }\end{array}$} & $\begin{array}{l}\text { Develop, launch, and manage new campaign } 1 \mathrm{x} \text { per } \\
\text { month }\end{array}$ & $\mathrm{CMO}$ \\
\hline & $\begin{array}{l}\text { Initiate copywriting and attractive poster for personal } \\
\text { selling ( } 1 \text { for every month), Shares to } 100 \text { persons }\end{array}$ & $\mathrm{CMO}$ \\
\hline & $\begin{array}{l}\text { Coordinated with team to Oversee, plan, and deliver } \\
\text { content ideas spreadsheet } 1 \mathrm{x} \text { per week ( } 2 \text { content per } \\
\text { founder) }\end{array}$ & $\mathrm{CMO}$ \\
\hline \multirow{3}{*}{$\begin{array}{l}\text { Increase } \\
\text { (minimum } \quad 30 \\
\text { products sold for a } \\
\text { month) }\end{array}$} & Doing social media advertising at least once a month & $\mathrm{CFO}$ \\
\hline & $\begin{array}{l}\text { Paid promotion to digital media on Instagram } 2 \mathrm{x} \text { per } \\
\text { weeks }\end{array}$ & $\mathrm{CFO}$ \\
\hline & $\begin{array}{l}\text { Subscription of online courses (skill academy, coursers) } \\
\text { and webinars at least once a week }\end{array}$ & $\mathrm{CFO}$ \\
\hline \multirow{3}{*}{$\begin{array}{l}\text { New } r \text { product } \\
\text { launch: } \\
\text { Bundling Products } \\
\& \text { 1 New product } \\
\text { variants }\end{array}$} & Consultation with expert to make product formulation & CEO \\
\hline & Seek and make contracts with all related stakeholders & $\mathrm{CEO}$ \\
\hline & Design and test the product (trial and errors) & CEO \\
\hline \multirow{3}{*}{$\begin{array}{l}\text { Website } \\
\text { Optimization }\end{array}$} & Optimize website with SEO & WS \\
\hline & $\begin{array}{l}\text { Develop and launch new product feature such as sleep } \\
\text { exercise }\end{array}$ & WS \\
\hline & Domain and hosting purchasing \& Programming & WS \\
\hline \multirow[t]{3}{*}{ Learning Program } & $\begin{array}{l}\text { Read books/journals/other sources of information once a } \\
\text { week and share knowledge results in weekly meetings }\end{array}$ & $\begin{array}{c}\text { ALL } \\
\text { MEMBER }\end{array}$ \\
\hline & Take online courses/classes or webinars $2 \mathrm{x}$ a month & $\begin{array}{c}\text { ALL } \\
\text { MEMBER }\end{array}$ \\
\hline & $\begin{array}{l}\text { Conduct consultation sessions at least } 2 \mathrm{x} \text { a week (with a } \\
\text { mentor or consultant) }\end{array}$ & $\begin{array}{c}\text { ALL } \\
\text { MEMBER }\end{array}$ \\
\hline
\end{tabular}

The Parameters For Evaluating The Plan Implementation Of Learning Organization Practices At Savlee Company

Based on Jann Hidayat's Knowledge Management Implementation Strategy book (2017), the evaluation stage serves to improve various components (people, systems/processes, and technology) in building organizational learning. The evaluation method will be conducted after the process of assessing the implementation of organizational learning. The process of measuring work performance compared to performance targets as a reference for evaluating organizational learning. In the case of Savlee's business, to evaluate the implementation of 
Volume 3 Issue 9 (September 2021) PP. 362-376 DOI 10.35631/AIJBES.39024

organizational learning, there are several stages that must be carried out by the Savlee company, such as:

1. Objective Key Result

The author will use OKR as a reference for measuring business progress and achieving targets. From this OKR, the CEO can find out how big the deviation is between progress compared to the target so that improvement plans and/or organizational learning practice initiatives can be formulated so as not to deviate from or business goals (Cox, Issa, \& Ahrens, 2003; Iveta, 2012).From this OKR, Savlee can identify overall business progress and the results of the achievement can be used as parameters in providing rewards for members.

2. Measuring performance by taking into account Return on Investment (ROI), wherein in the implementation of organizational learning there is capital that must be invested in procuring processes, technology, and infrastructure to carry out organizational learning. In Savlee cases, there are added capital investment to empower management, such as procurement of consultants and all costs for conducting employee programs and training, capital related to business process procurement such as business axis capital, licensing arrangements, etc. , and capital-related to infrastructure procurement in the form of online classes/courses and webinars.

3. Conducting an ongoing evaluation process by producing recommendations for improving the organizational learning implementation process.

\section{Conclusion}

Based on the results of research conducted by the author, it is known that the House of Learning Organization Jann Model and The Dance of Profound Change Peter Senge influence the Learning Organization Practice for Savlee company in increasing Savlee's Business Performance. On the research questions, the authors proposed three research questions through this research which have been analyzed in data findings and discussion as follows:

\section{Research Question 1:}

What are the best suitable learning organization practices in Savlee Company?

There are several problems and challenges that arise in Savlee's business productivity. The change in the business model represents a significant change in Savlee's business progress. Savlee's business has brought significant changes to the target market. Savlee began to study a new approach in the fields of pharmacy, psychology, and neuroscience. Savlee needed to have an initial learning and was seeking a new form of information that became the main reference.

Based on the results of problem identification in Savlee's company, it is necessary to arrange the new learning organization practices at Savlee Company to increase business productivity. It is conducted as a test of Savlee company's readiness to implement organizational learning practices by focusing on the fundamentals of the House of Learning Organization by Jann Model (2006). This model focuses on the effectiveness of the organizational learning process by analyzing the quality of the three elements of the learning organization (humans, technology, and habitat). The conceptual and characteristics of the learning organization can be developed based on the building of the learning organization as follows: Leadership, Learning Foundation, Learning Skills, Learning Facilities, and Learning Discipline. 
Volume 3 Issue 9 (September 2021) PP. 362-376

DOI 10.35631/AIJBES.39024

The learning quality test and member maturity test using the House of Learning Organization Jann model (2006), show that Savlee has met the indicators of a good learning habitat and Savlee members are already mature enough to change into a learning organization. The existence of maturity in Savlee members is also in line with Jann Hidayat's research in 2001, which concluded that the process of sharing knowledge requires a learning habitat that is based on mutual trust between members in dialogue, belief in the growth of the process of educating each other, and producing mutual benefits. With the fulfillment of the five disciplines of Peter Senge's (1994) learning organization, it can act as a developmental path for acquiring certain skills or competencies for organization capital. With the fulfillment of the five disciplines of Peter Senge's learning organization (1994), this indicates that there is a harmonious relationship between humans and habitat as human capital in building learning organization practice.

\section{Research Question 2:}

\section{How To Design Steps For Implementing Learning Organization Practice On Influencing Business Performance On Savlee Company Cases?}

The design plan for implementation of the learning organization will refer to developed Peter Senge methods, using The Dance of Change-Generating Profound Change. The steps of the deep change process to realize the learning organization model consist of the following three stages of change:

1. Vision/Target/Objectives in Implementing Learning Organization Practice

a. Savlee must conduct a dialogue process (share values, share vision, or share knowledge) to build shared intelligence and attract commitment from each member to form Savlee as a learning company.

b. Develop a comprehensive smart work plan as a coordination and control system for the implementation learning organization. Starting from the preparation stage, identification stage, habitat building stage, organizational learning implementation stage, and evaluation stage. It will produce a roadmap and OKR as performance measurement tools (process, progress, and results) that are effective in building organizational learning.

c. Creating a learning habitat that is able to motivate and support members to create innovations for solving problems and challenges that arise from Savlee's business changes.

2. Building Individual Learning Skills to Produce Personal Mastery by building inner shift and outer shift. At this stage, Savlee focuses on building a learning culture with a routine knowledge sharing program and creating reward systems based on the achievement of the company.

3. Building Team Learning Ability to Increase the Effectiveness of the Knowledge Sharing Process Between Members in the form of Objective Key Results (OKR), which consists of vision and objectives, determining policies and work organization, knowledge flow model, and road map. Savlee's key result objectives include increasing awareness on social media, increasing sales (minimum 30 products sold in a month), launching new products (1 product bundle $\& 1$ new product variant), website optimization, and conducting learning programs.

4. Building Organizational Learning Ability to Generate Human Capital. In this stage, Savlee focuses on creating organizational human capital by providing consultants and online courses and class facilities. 


\section{Research Question 3:}

\section{What Is The Right Measurement Method To Measure The Success Of Implementing Learning Organization Practice At Savlee?}

Based on Jann Hidayat's Knowledge Management Implementation Strategy book (2017), this evaluation stage serves to improve various components (people, systems/processes, and technology) in building organizational learning. The evaluation method carried out after the company carried out the process of assessing the success of organizational learning implementation, such as the process of measuring work performance compared to performance targets as a reference for evaluating organizational learning. To evaluate the implementation of organizational learning, there are several stages that must be carried out by the Savlee company, such as:

1. Objective Key Result

The author will use OKR as a reference for measuring business progress and achieving targets. From this OKR, the CEO can find out how big the deviation is between progress compared to the target, so that improvement plans and/or organizational learning practice initiatives can be formulated so as not to deviate from business goals. From this OKR, Savlee can identify overall business progress and the results of the achievement can be used as parameters in providing rewards for members.

2. Measuring performance by taking into account Return on Investment (ROI), where in the implementation of organizational learning there is capital that must be invested in procuring processes, technology, and infrastructure to carry out organizational learning. For example, capital to empower management, such as procurement of consultants and all costs for conducting employee programs and training, capital related to business process procurement, such as business axis capital, licensing arrangements, etc., and capital related to infrastructure procurement in the form of online classes/courses and webinars.

3. Conducting an ongoing evaluation process by producing recommendations for improving the organizational learning implementation process.

\section{Recommendations}

\section{Research Implications}

The author has several recommendations for Savlee to improve various components (people, systems/processes, and technology) in building organizational learning based on the results obtained from the analysis and discussion in chapter 5, namely that Savlee members are expected to conduct a dialogue process (share values, share vision, or share knowledge) to build shared intelligence and attract commitment from each member to form Savlee as a learning company. Develop a comprehensive smart work plan as an organizational learning implementation process starting from the preparation stage, identification stage, habitat building stage, organizational learning implementation stage, and evaluation stage. At this stage, they will produce a class work plan as well as performance measurement tools (process, progress, and results) that are effective in building organizational learning, and Creating a learning habitat that is able to motivate and support members to create innovations for solving problems and challenges that arise from Savlee's business changes. Where this becomes very crucial in ensuring the implementation of organizational learning practices. Therefore, the evaluation process can be carried out if the organization has carried out the process of assessing the success of organizational learning implementation, such as the process of measuring work 
performance compared to performance targets as a reference for evaluating organizational learning.

\section{Future Research}

For further research, the author has concluded several recommendations for researchers who intend to research similar topics and plan to use this research as their reference. The first thing to pay attention to is the scope and limitations of its business. Savlee is a small business that has just pivoted its business model, so in implementing organizational learning it takes some adjustments to adapt to the existing learning habitat. In addition, in terms of business scope, there will be changes in the implementation of learning organization practice if Savlee has additional members of more than 20 people or if Savlee's company has developed with a larger scope. So, the implementation of learning organization practice will be developed into a knowledge management system run by the company without time limit. In choosing a learning organization practice model, the researcher can explore other organizational learning methods or knowledge management to be implemented according to the conditions or cases encountered. It will help the researcher to provide wider knowledge and perspective for the researcher to understand the concept of implementing organizational learning in small companies. Another thing, in data collection, it is better to do an offline FGD to get deeper information and be able to explore hidden assumptions about a problem. So the results will be much more precise and accurate to be implemented in the company.

\section{References}

Afiyanti, Y. (2008). Focus Group Discussion Sebagai Metode Pengumpulan Data Penelitian Kualitatif. Jurnal Keperawatan Indonesia, 12(1), 58-62. Https://Doi.Org/10.7454/Jki.V12i1.201

Aprisma, Reyry, Sudrayanti, Erina. 2020. Environmental Uncertainty And Firm Performance: The Moderating Role Of Corporate Governance. Surabaya : Jurnal Akuntansi. Retrieved On Ecojoin.Org 30 April 2021. (Doi: Http://Dx.Doi.Org/10.24912/Ja.V24i2.690)

Bengtsson, M. (2016). Linking Evidence To Practice: A Clinical Practice Guideline Project. Nursingplus Open, 2, 26-34. Https://Doi.Org/10.1016/J.Npls.2016.09.002

Farhana, K. (2021, March 27). Serba-serbi Masalah Tidur Di Tengah Pandemi Corona. Fimela.Com.

Fink, Arlene. Conducting Research Literature Reviews: From The Internet To Paper. Fourth Edition. Thousand Oaks, Ca: Sage, 2014.Fink, Arlene. Conducting Research Literature Reviews: From The Internet To Paper. Fourth Edition. Thousand Oaks, Ca: Sage, 2014.

Fiol, C., \& Lyles, M. (1985). Organizational Learning. The Academy of Management Review, 10(4), 803-813. doi:10.2307/258048

Garvin, D. A. (2014, August 1). Building a Learning Organization. Performance Measurement. https://hbr.org/1993/07/building-a-learning-organization.

Genio, K., 2016. An Analysis Of Recruitment And Job Training Method Effectiveness To Employee Engagement In Bandung Culinary Start-up. P. 1.

Gray, David E. And Tam, Steven (2016) The Practice Of Employee Learning In Sme Workplaces: A Micro View From The Life-cycle Perspective. Journal Of Small Business And Enterprise Development, 23 (3). Pp. 671-690. Issn 1462-6004 (Doi:Https://Doi.Org/10.1108/Jsbed-07-2015-0099)

Robillard, R., Dion, K., Pennestri, M., Solomonova, E., Lee, E., Saad, M., Murkar, A., Godbout, R., Edwards, J., Quilty, L., Daros, A., Bhatla, R. And Kendzerska, T., 2020. Profiles Of Sleep Changes During The Covid-19 Pandemic: Demographic, Behavioural 
And Psychological Factors. Journal Of Sleep Research, [Online] 30(1). Available At: [Accessed 30 April 2021].

Karadag, E., Samancioglu, S., Ozden, D., \& Bakir, E. (2015). Effects Of Aromatherapy On Sleep Quality And Anxiety Of Patients. Nursing In Critical Care, 22(2), 105-112. Doi:10.1111/Nicc.12198

Robillard, R., Dion, K., Pennestri, M., Solomonova, E., Lee, E., Saad, M., Murkar, A., Godbout, R., Edwards, J., Quilty, L., Daros, A., Bhatla, R. and Kendzerska, T., 2020. Profiles of sleep changes during the COVID-19 pandemic: Demographic, behavioural and psychological factors. Journal of Sleep Research, [online] 30(1). Available at: $<$ https://onlinelibrary.wiley.com/doi/epdf/10.1111/jsr.13231> [Accessed 30 April 2021].

Senge, Peter. 1990. The Fifth Dicipline : The Art \& Practice of The Learning Organization. Doubleday. ISBN 0-385-26095-4

Taherdoost, Hamed, 2020. . Sampling Methods in Research Methodology; How to Choose a Sampling Technique for Research. International Journal of Academic Research in Management (IJARM), 2016, 5. Ffhal-02546796f

Tjaakraatmadja, J. H. (2006). Knowledge Management dalam Konteks Organisasi Pembelajar. SBM-ITB (Sekolah Bisnis dan Management - Institut Teknologi Bandung. ISBN 9795458-0-4

Tjakraatmadja, J. H. (2017). Strategi Implementasi Knowledge Management. Institut Teknologi Bandung. ISBN 978-602-5417-02-3 